J. Clin. Chem. Clin. Biochem.

Vol. 19, 1981, pp. 363-370

\title{
Synthesis of Hepatic Glycosaminoglycans in the Early Stages of Galactosamine Hepatitis: A Rapid Decline of Heparan Sulfate is Followed by Elevation of Chondroitin Sulfate and Dermatan Sulfate
}

\author{
By A. M. Gressner and W. Köster-Eiserfunke \\ Department of Clinical Chemistry and Pathobiochemistry of the Medical Faculty of the Technical University \\ (RWTH) Aachen, FRG
}

(Received June 24, 1980/January 13, 1981)

Summary: Administration of a single dose of $D$-galactosamine to rats causes time-dependent, biphasic changes of total glycosaminoglycan synthesis in liver. A rapidly occurring inhibition is followed by a significantly enhanced $\left(>2\right.$ fold) production of ${ }^{35}$ S-labeled glycosaminoglycans in later stages of injury. Degree and duration of the inhibitory phase are dose-dependent; $50 \%$ inhibition is reached at $80 \mathrm{mg} / \mathrm{kg}$ and maximum inhibition (nearly $80 \%$ ) at about $300 \mathrm{mg} / \mathrm{kg}$ body weight $2 \mathrm{~h}$ after injection of $D$-galactosamine.

The hepatotoxin impairs preferentially the production of heparan sulfate, whereas that of chondroitin sulfate and dermatan sulfate is diminished only slightly and for a rather short period of time. The synthesis of the latter, however, is more stimulated than that of heparan sulfate in later stages of injury.

The specific radioactivity of ${ }^{35}$ S-labeled 3'-phosphoadenosine-5'-phosphosulfate (PAPS) did not change significantly during the course of acute liver damage.

Glycosaminoglycan synthesis in regenerating liver was nearly unaffected by $D$-galactosamine. Uridine at the dose applied partially reversed $D$-galactosamine-inhibited synthesis of proteoheparan sulfate.

In accordance with the labeling studies the content of glucosamine-containing glycosaminoglycans in treated liver decreased, whereas that of galactosamine-containing glycosaminoglycans slightly increased, resulting in a nearly 50\% reduction of the glucosamine/galactosamine ratio $5 \mathrm{~h}$ after administration of $D$-galactosamine. Ion exchange chromatographic studies of ${ }^{35} \mathrm{~S}$-labeled specific types of glycosaminoglycans from normal and galactosamine-injured liver revêaled oñly minor structurạl differences.

Synthese der Leberglykosaminoglykane in den Frühstadien der Galaktosamin-Hepatitis: Einer raschen Erniedrigung des Heparansulfates folgt eine Erhöhung von Chondroitinsulfat und Dermatansulfat

Zusammenfassung: Eine Ėinzeldosis von $D$-Galaktosamin erzeugt in der Rattenleber zeitabhängige, biphasische Veränderungen dẹ Glykosaminoglykansynthese. Eine sofort eintretende Hemmung wird gefolgt von einer signifikant erhöhten (über 2 fach) Produktion ${ }^{35}$ S-markierter Glykosaminoglykane in späteren Stadien der Schädigung. Grad und Dauer der inhibitorischen Phase sind dosisabhängig; $50 \%$ der Hemmung tritt bei $80 \mathrm{mg} / \mathrm{kg}$ und maximale Hemmung (nahezu $80 \%$ ) bei etwa $300 \mathrm{mg} / \mathrm{kg}$ Körpergewicht 2 Stunden nach Verabreichung von $D$-Galaktosamin ein. Das hepatotoxische $D$-Galaktosamin beeinträchtigt vorzugsweise die Produktion von Heparansulfat, wohingegen die Synthese von Chondroitinsulfat und Dermatansulfat nur geñinggradig und für einen kurzen Zeitraum vermindert ist. Die Bildung der letztgenannten Glykosaminoglykäne wird jedoch in späteren Stadien der Schädigung stärker als die von Heparansulfat stimuliert.

Die spezifische Radioaktivität von ${ }^{35}$ S-markiertem $3^{\prime}$ 'Phosphoadenoșin-5'-phosphosulfat (PAPS) verändert sich im Verlauf der akuten Leberschädigung nicht signifikant. 
Die Glykosaminoglykansynthese in der regenerierenden Leber wird durch $D$-Galaktosamin nicht beeinflußt, Uridin in der angegebenen Dosierung führt zu einer partiellen Reversibilität der $D$-Galaktosamin bedingten Hemmung der Synthese von Proteoheparansulfat.

In Ubereinstimmung mit den Markierungsstudien nimmt die Konzentration Glucosamin-enthaltender Glykosaminoglykane in der behandelten Leber ab, wohingegen die der Galaktosamin-enthaltenden Glykosaminoglykane geringgradig ansteigt. Dies führt zu einer Reduktion des Glucosamin/Galaktosamin Verhältnisses um nahezu $50 \% 5 \mathrm{~h}$ nach Gabe von $D$-Galaktosamin.

Ionenaustauschchromatographische Untersuchungen ${ }^{35}$ S-markierter spezifischer Typen der Glykosaminoglykane von normalen und Galaktosamin-geschädigten Lebern ließen nur geringe strukturelle Ünterschiede erkennen.

\section{Introduction}

Administration of $D(+)$-galactosamine to rats causes acute liver damage, which resembles biochemically and morphologically human viral hepatitis (1-5). The primary pathobiochemical lesions initiated by the hepatotoxic $D$-galactosamine have been studied in detail and found to be an intracellular depletion of uridine phosphates and UDP-sugars accompanied by an accumulation of UDP-hexosamines (6-9). Much less is known, however, about the molecular mechanisms of the subsequent events, such as the inhibition of macromolecular syntheses, and hence about their contribution to the death of the hepatocyte. Recently, the liver cell plasma membrane has been identified as the key target organelle of galactosamine-hepatotoxicity (10-13). It is known that several types of proteoglycans, in particular proteoheparan sulfate, are intimately associated with the surface of the hepato-cellular membranes (14-17). Although the functions of the cell coat proteoglycans are only speculative at present their ubiquity, high metabolic rate and structural heterogeneity suggest a significant role in normal cellular metabolism (18, 19). Conversely, perturbations of the synthesis of proteoheparan sulfate during the course of galactosamine-induced liver damage might be meaningful for the pathogenesis of hepatocellular necrosis. This prompted us to study the hepatic synthesis of total and specific types of glycosaminoglycans during the early phase of galactosamine-provoked liver injury and in galactosamine-refractory regenerating liver (20).

\section{Materials and Methods}

\section{Materials}

$D$-Galactosamine $\cdot \mathrm{HCl}$ was obtained from C. Roth OHG, Karlsruhe; uridine (crystalline, Sigma grade) from Sigma Chemical Company, Munich; chondroitin AC (EC 4.2.2.5) and chondroitin ABC (EC 4.2.2.4) lyases were from Seikagaku Kogyo Comp., Tokyo, Japan; papain (EC 3.4.22.2, crystalline suspension, $30 \mathrm{U} / \mathrm{mg}$ protein) was from Boehringer Mannheim $\mathrm{GmbH}$; sodium $\left[{ }^{35} \mathrm{~S}\right]$ sulfate (carrier free) and $3^{\prime}$-phosphoadenosine$5^{\prime}$-phosphosulfate (tetrasodium salt, $3^{\prime}=\left[{ }^{35} \mathrm{~S}\right], 10.73 \mathrm{TBq} / \mathrm{mol}$ $(0.29 \mathrm{Ci} / \mathrm{mmol})$, lot. $1255-263)$ were from New England Nuclear Corp., Boston, USA; harmol $\cdot \mathrm{HCl}$ (lot. $63 \mathrm{C}-1330$ ) was from Sigma Chemical Comp., Munich, FRG and thin-layer chromatography plates (CEL 300-25) were purchased from Macherey-Nagel Co., Düren, FRG.

\section{Treatment of rats}

Male Sprague-Dawley rats (Zentralinstitut für Versuchstiere, Hannover, FRG) weighing $260 \pm 30 \mathrm{~g}$ had free access to a standard rat diet and water throughout the experimental period. They were injected intraperitoneally between $8: 00$ and 10:00 a.m. with variable amounts of $D$-galactosamine $\cdot \mathrm{HCl}$, freshly dissolved in $0.154 \mathrm{~mol} / 1$ of $\mathrm{NaCl}$. The precise doses are given in the legends of the appropriate figures and tables. Control rats received an equal volume of $\mathrm{NaCl}$ alone. Uridine, dissolved in isotonic $\mathrm{NaCl}$, was administered intraperitoneally in a dose of $272 \mathrm{mg} / \mathrm{kg}$ body weight. Partial hepatectomy (21) was performed under light ether anaesthesia between 8:30 and 10:00 a.m.; control animals were operated similarly but their livers were replaced in the abdomen after being exposed for about $30 \mathrm{~s}$ (sham-operated rats). Thirty min prior to decapitation the rats received intraperitoneally $3.7 \mathrm{MBq}$ of $\left[{ }^{35} \mathrm{~S}\right]$ sulfate dissolved in $0.2 \mathrm{ml}$ of $0.154 \mathrm{~mol} / \mathrm{l}$ of NaCl .

Incorporation of $\left[{ }^{35} \mathrm{~S}\right]$ sulfate into total glycosaminoglycans After decapitation the livers were quickly removed, minced and carefully freed of blood in ice-cold buffer $(0.05 \mathrm{~mol} / 1$ Tris$\mathrm{HCl}, \mathrm{pH} 7.6\left(20^{\circ} \mathrm{C}\right), 0.08 \mathrm{~mol} / 1 \mathrm{KCl}, 0.0125 \mathrm{~mol} / 1 \mathrm{MgCl}_{2}$, $0.25 \mathrm{~mol} / 1$ sucrose). The tissue was defatted by repeated washings each with 10 volumes of cold acetone, chloroform-methanol (volumes, $200 \mathrm{ml}+100 \mathrm{ml}$ ), and ethanol-ether (volumes, $300 \mathrm{ml}+100 \mathrm{ml}$ ). Subsequently it was dried for $24 \mathrm{~h}$ at $60^{\circ} \mathrm{C}$, weighed and proteolysed for 2 days in papain-buffer (22) at $65^{\circ} \mathrm{C}$ with two separate additions of 5 and $2.5 \mathrm{mg}$ of papain, respectively. The digestion was terminated with $50 \mathrm{~g} / 1$ of trichloroacetic acid and the supernatant obtained after centrifugation $\left(2000 \mathrm{~g}, 15 \mathrm{~min}, 0^{\circ} \mathrm{C}\right)$ neutralized and dialy sed at $4{ }^{\circ} \mathrm{C}$ against 50 volumes of $0.03 \mathrm{~mol} / 1$ of $\mathrm{NaCl}$. After addition of unlabeled glycosaminoglycans as carrier the radiolabeled glycosaminoglycans were precipitated with cetylpyridinium chloride as described previously $(23,24)$. The final sediment containing total glycosaminoglycans was dissolved in water and a portion was counted in a liquid scintillation spectrometer with an efficiency of 0.81 for ${ }^{35} \mathrm{~S}$.

\begin{abstract}
Incorporation of $\left[{ }^{35} \mathrm{~S}\right]$ sulfate into specific types of glycosaminoglycans

${ }^{35}$ S-labeled glycosaminoglycans were subjected to enzymatic analysis with chondroitin $\mathrm{AC}$ and $\mathrm{ABC}$ lyases and to degradation with nitrous acid. The details of the procedures and the calculation of the results have been reported elsewhere (23). The amount of $\left[{ }^{35} \mathrm{~S}\right]$ sulfate incorporated into total and individual glycosaminoglycans is referred to liver dry weight.
\end{abstract}

\footnotetext{
Determinations of concentration and specific radioactivity of 3'-phosphoadenosine-5'-phosphosulfate (PAPS) in rat liver

Concentrations and specific activity of PAPS in normal and galactosamine-injured liver were determined by a recently developed fluorimetric assay (25). Immediately after decapitation a portion of the ${ }^{35} \mathrm{~S}$-labeled liver was frozen and pulverized in liquid nitrogen, of which $1 \mathrm{~g}$ was dentatured in $2 \mathrm{ml}$ of boiling buffer $\left(0.5 \mathrm{~mol} / \mathrm{l}\right.$ gly cine, $\mathrm{pH} 9.2\left(20^{\circ} \mathrm{C}\right)$.
} 
After homogenization and centrifugation $(30 \mathrm{~min}, 15,000 \mathrm{~g}$, $2{ }^{\circ} \mathrm{C}$ ) the supernatant containing PAPS was extracted with chloroform. The water phase was incubated for $1 \mathrm{~h}$ at $37^{\circ} \mathrm{C}$ with harmol in the presence of $178000 \mathrm{~g}$ dog liver supernatant. After termination and chloroform extraction harmo sulfate was separated from harmol by thin-layer chromatography (25) giving $R_{\mathrm{f}}$ values of 0.5 and 0.75 respectivcly. UV-visible spots containing harmol sulfate were scraped from the plate and desorbed with $0.1 \mathrm{~mol} / 1 \mathrm{HCl}$. In the cluate radioactivity was measured and concentration of harmol was determined fluorimetrically (excitation $315 \mathrm{~nm}$, emission above $400 \mathrm{~nm}$ ) using an Eppendorf $1101 \mathrm{M}$ photometer with fluorescence equipment. A calibration curve ranging from 2 to 200 $\mathrm{nmol} / \mathrm{l}$ was established for harmol. The intra-assay $\mathrm{CV}$ was about $15 \%$ and the recovery of authentic PAP[ $\left.{ }^{35} \mathrm{~S}\right]$ was about 0.8 .

\section{Ion exchange chromatography of ${ }^{35}$ S-labeled liver glycos-} aminoglycans

Total glycosaminoglycans from liver of normal and galactosamine-treated rats isolated as outlined above were chromatographed on columns $(0.6 \times 13 \mathrm{~cm})$ of Dowex $1 \times 2\left(\mathrm{Cl}^{-}, 200\right.$ 400 mesh) by stepwise elution with each $50 \mathrm{ml}$ of $0.5,1.0$, $1.25,2.0$, and $3.0 \mathrm{~mol} / 1$ of $\mathrm{NaCl}$. The eluates were dialysed against water, lyophylised and subjected to enzymatic and chemical identification as described above.

\section{Determination of hexosamines in total hepatic glycosamino-} glycans

$D$-Galactosamine-treated and untreated (control) rat livers were defatted, dried, weighed, and proteoly sed as described above. The proteoly sate was dialy sed against $0.5 \mathrm{~mol} / 1$ of $\mathrm{NaCl}$ and applied to a column $(0.6 \times 13 \mathrm{~cm})$ of Dowex $1 \times 2$ equilibrated with $0.5 \mathrm{~mol} / 1$ of $\mathrm{NaCl}$. After extensive washing the column was eluted with $30 \mathrm{ml}$ of $3.0 \mathrm{~mol} / \mathrm{l}$ of $\mathrm{NaCl}$ and the eluate was concentrated, dialysed against $0.03 \mathrm{mul} / 1$ of $\mathrm{NaCl}$ and precipitated with cetylpyridinium chloride (23). The precipitate was hydrolyzed in $3 \mathrm{~mol} / 1$ of $\mathrm{HCl}$ for $15 \mathrm{~h}$ at $105^{\circ} \mathrm{C}$ and for quantitation of hexosamines applied to a Biotronik Amino Acid Analyzer LC 2000 equipped with a fluorescence detector BT 6630 .

\section{Results}

Effect of D-galactosamine on the incorporation of $\left[{ }^{35} \mathrm{~S}\right]$ sulfate into total and specific glycosaminoglycans of liver

Normal rat liver incorporates very rapidly but at markedly different rates intraperitoneally applied $\left[{ }^{35} \mathrm{~S}\right]$ sulfate into the various types of glycosaminoglycans; 0.8 of the total glycosaminoglycan-associated radioactivity (1.4 $\mathrm{kBq} / \mathrm{g}$ liver dry weight $\cdot 0.5 \mathrm{~h}^{-1}$ ) is found in nitrous acidlabile material (heparan sulfate) whereas only 0.16 and 0.04 of total activity are linked to dermatan sulfate and chondroitin sulfate, respectively.

The administration of $700 \mathrm{mg} / \mathrm{kg}$ body weight of $D$ galactosamine to rats results in a prompt and severe inhibition of $\left[{ }^{35} \mathrm{~S}\right]$ sulfate incorporation into total hepatic glycosaminoglycans (fig. 1). As early as $30 \mathrm{~min}$ after application of the hepatotoxic $D$-galactosamine the incorporation is diminished by more than $80 \%$. Thereafter the production of labeled glycosaminoglycans increases gradually, reaching $50 \%$ inhibition at about $12 \mathrm{~h}$ and control values at about $22 \mathrm{~h}$ after onset of treatment. 2 days after injection of $D$-galactos- amine the incorporation of $\left[{ }^{35} \mathrm{~S}\right]$ sulfate into liver glycosaminoglycans is significantly stimulated.

The inhibition of total glycosaminoglycan synthesis by $D$-galactosamine follows a dose-response curve (fig. 2) which shows $50 \%$ inhibition at $80 \mathrm{mg} / \mathrm{kg}$ and maximum inhibition (about $80 \%$ ) at about $300 \mathrm{mg} / \mathrm{kg}$ body weight.

Further studies were performed to analyse the production of ${ }^{35}$ S-labeled specific types of glycosaminoglycans in response to galactosamine-induced hepatic damage. Figure 1 demonstrates that the hepatotoxic $D$-galactosamine greatly diminished the formation of heparan $\left[{ }^{35} \mathrm{~S}\right]$ sulfate between 0.5 and $6 \mathrm{~h}$ after administration. During this period heparan sulfate production was only 0.05 of that of untreated rats; it increased to control values $40 \mathrm{~h}$ after the beginning of the treatment. In contrast to heparan sulfate the labeling of chondroitin sulfate and dermatan sulfate was reduced only slightly and for a rather short period of time (between 0.5 and $1 \mathrm{~h}$ ). It is of interest that the rate of chondroitin $\left[{ }^{35} \mathrm{~S}\right]$ sulfate

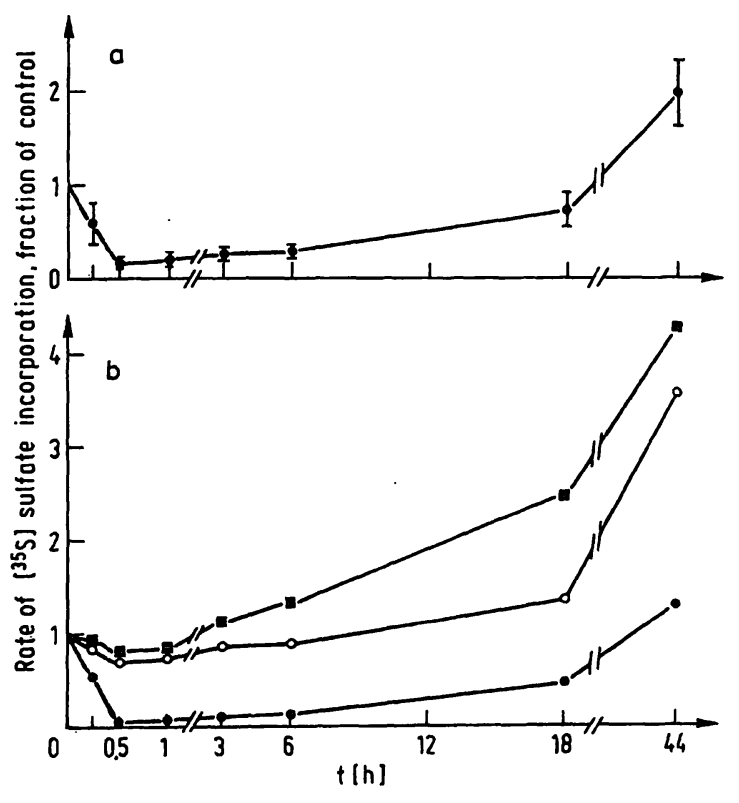

Fig. 1. The synthesis of ${ }^{35} \mathrm{~S}$-labeled glycosaminoglycans in liver treated for various times with $D$-galactosamine.

Rats were injected with $700 \mathrm{mg} / \mathrm{kg}$ body weight or a similar volume of $0.154 \mathrm{~mol} / 1$ of $\mathrm{NaCl}$ (control) and received at the times indicated $3.7 \mathrm{MBq}$ of $\left.\left.\right|^{35} \mathrm{~S}\right]$ sulfatc $30 \mathrm{~min}$ before decapitation. The livers were removed, defatted, dried, weighed and proteolysed in order to isolate total glycosaminoglycan-associated radioactivity. The incorporation of radioactivity into specific types of sulfated glycosaminoglycans was assayed by chemical (heparan sulfate) and enzy matic procedures (chondroitin sulfate, dermatan sulfate). The amount of glycosaminoglycan-bound $\left.\right|^{35}$ S] sulfate was referred to defatted liver dry weight. The incorporation of the isotope into total (a) and specific glycosaminoglycans (b, - chondroitin sulfate, $0 \longrightarrow$ dermatan sulfate, $\bullet \longrightarrow$ heparan sulfate) of galactosamine-treated liver is expressed as fraction of incorporation into glycosaminogly cans of the appropriate control livers. Each value represents the mean $\pm S$.D. of 3 to 4 independent experiments. 


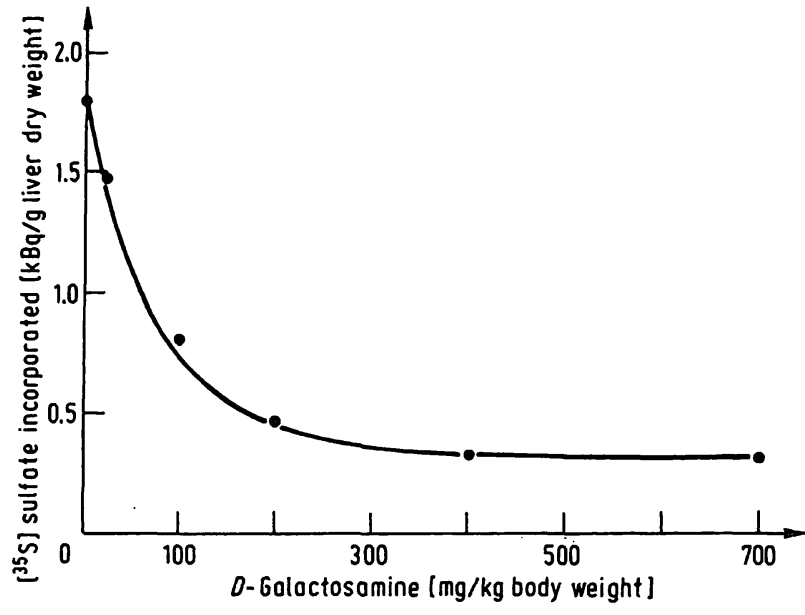

Fig. 2. Dose-response curve of the effect of $D$-galactosamine on the incorporation of $\left[^{35} \mathrm{~S}\right]$ sulfate into total hepatic glycosaminoglycans. Rats received intraperitoneally variable amounts of $D$-galactosamine. $2 \mathrm{~h}$ later and $30 \mathrm{~min}$ before decapitation $3.7 \mathrm{MBq}$ of ( $^{35}$ S ] sulfate was administered to each animal. Unfractionated labeled glycosaminogly cans were isolated from the liver as described in the legend of fig. 1 . The values are the mean of duplicate determinations.

formation began to increase $3 \mathrm{~h}$ after initiation of liver damage, reaching greatly elevated levels after 2 days. A similar time-course of $\left[{ }^{35} \mathrm{~S}\right]$ sulfate incorporation was observed for dermatan sulfate (fig. 1b).

Concentration and specific radioactivity of liver 3 '-phospho-adenosine-5'-phosphosulfate (PAPS) in response to D-galactosamine

The concentration of PAPS in normal rat liver was found to be $21.1 \pm 2.6 \mathrm{nmol} / \mathrm{g}$ wet weight (fig. 3 ). It increased, during the phase of maximal inhibition of heparan sulfate production, up to $25 \mathrm{nmol} / \mathrm{g}$ liver wet weight, but was greatly diminished in the later stages of injury when the production of chondroitin $\left[{ }^{35} \mathrm{~S}\right]$ sulfate and dermatan $\left[{ }^{35} \mathrm{~S}\right]$ sulfate was accelerated. The specific radioactivity of $\mathrm{PAP}\left[{ }^{35} \mathrm{~S}\right]$ in liver, however, did not change significantly during the course of acute liver damage. Therefore, changes in the rates of incorporation of the isotope into

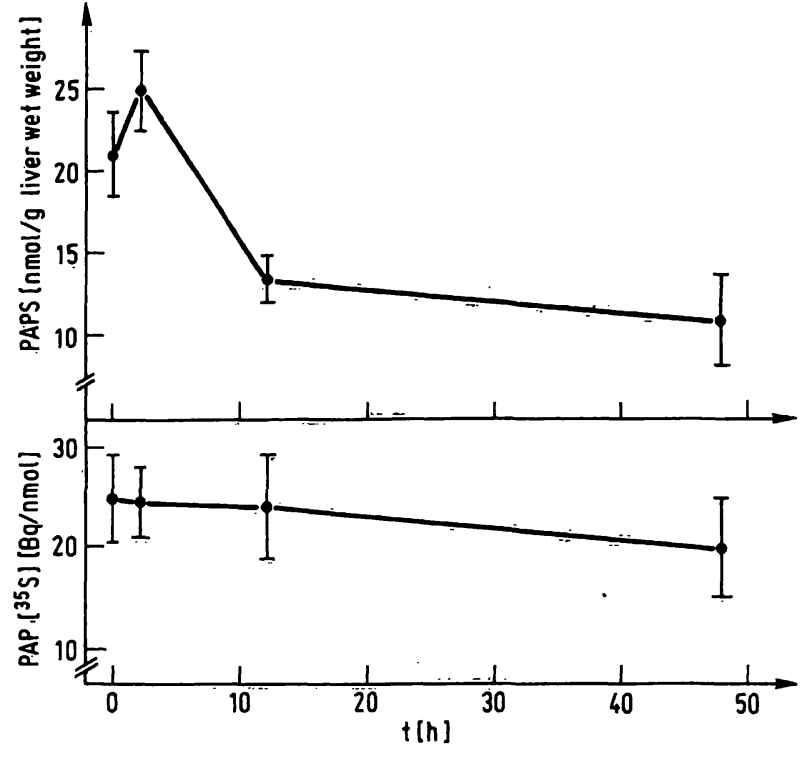

Fig. 3. Concentration and specific radioactivity of 3'-phosphoadenosine- $5^{\prime}$-phosphosulfate in rat liver following administration of $D$-galactosamine.

Rats were injected with $700 \mathrm{mg} / \mathrm{kg}$ body weight of $D$-galactosamine and received at the times indicated $30 \mathrm{~min}$ before decapitation $3.7 \mathrm{MBq}$ of $\left[{ }^{35} \mathrm{~S}\right]$ sulfate. Portions of the liver were frozen in liquid nitrogen, weighed and applied to fluorimetric quantitation and determination of specific activity of PAPS. The mean values \pm S.D. of 3 to 4 independent experiments are given.

the glycosaminoglycans obviously do not reflect variations in the specific radioactivity of activated sulfate.

\section{Effect of D-galactosamine on the incorporation of $\left[{ }^{35}\right.$ S] sulfate into glycosaminoglycans of regenerating liver}

The synthesis of $\left[{ }^{35} \mathrm{~S}\right] \mathrm{glyc}$ cosaminoglycans in proliferating rat liver two days after partial hepatectomy is only moderately inhibited by $D$-galactosamine (tab. 1). In sham-operated livers, however, the incorporation of the isotope into total glycosaminoglycans decreases from 3.3 to $2.3 \mathrm{kBq} / \mathrm{g}$ liver dry weight. The data summarized in table 1 show that the production of

Tab. 1. The effect of $D$-galactosamine on the incorporation of ${ }^{35} \mathrm{~S} \mid$ sulfate into specific glycosaminoglycans of regenerating liver. Rats were partially hepatectomized or sham-operated 2 days before intraperitoneal administration of $200 \mathrm{mg} / \mathrm{kg}$ body weight. Control rats received $\mathrm{NaCl}$ instead of $D$-galactosamine. $6 \mathrm{~h}$ after application of $D$-galactosamine and $30 \mathrm{~min}$ before decapitation $37 \mathrm{MBq}$ of $\left[{ }^{35} \mathrm{~S}\right]$ sulfate were injected. The incorporation of the isotope into individual glycosaminoglycans wạs determined as outlined in fig. 1 . The number of rats is given in parentheses.

Treatment of rats

\begin{tabular}{lllll} 
& & \multicolumn{2}{l}{ [kBq/g liver dry weight] } & Chondroitin sulfate \\
& & Heparan sulfate & Dermatan sulfate & Che \\
\hline Partial hepatectomy & $\mathrm{NaCl}$ & $3.02 \pm 0.43$ & $1.05 \pm 0.15$ & $0.33 \pm 0.04$ \\
$(\mathrm{n}=6)$ & Galactosamine & $2.74 \pm 0.86$ & $1.02 \pm 0.02$ & $0.33 \pm 0.02$ \\
Sham-operated & $\mathrm{NaCl}$ & $2.25 \pm 0.16$ & $0.66 \pm 0.05$ & $0.23 \pm 0.03$ \\
$(\mathrm{n}=6)$ & Galactosamine & $0.76 \pm 0.19$ & $0.76 \pm 0.02$ & $0.49 \pm 0.05$ \\
\hline
\end{tabular}


heparan $\left[{ }^{35} \mathrm{~S}\right]$ sulfate is reduced by less than $10 \%$ in regenerating liver $6 \mathrm{~h}$ after application of $D$-galactosamine, but in treated, sham-operated animals the incorporation of $\left[{ }^{35} \mathrm{~S}\right]$ sulfate into this type of glycosaminoglycans is diminished by about $70 \%$. Furthermore, the labeling of chondroitin sulfate and dermatan sulfate in response to $D$-galactosamine is quite different in proliferating and non-proliferating livers. In the latter the radioactivity associated with chondroitin sulfate and dermatan sulfate increases, whereas in regenerating liver galactosamine was without effect on the rate of incorporation of $\left[{ }^{35} \mathrm{~S}\right]$ sulfate into both types of glycosaminoglycans. Taken together the results demonstrate that under the experimental conditions described the synthesis of $\left[{ }^{35} \mathrm{~S}\right]$ glycosaminoglycans in regenerating rat liver is not inhibited by $D$-galactosamine.

\section{Effect of uridine on galactosamine-induced depression of $\left[{ }^{35} \mathrm{~S}\right]$ sulfate incorporation into liver glycosamino- glycans}

Another way to counteract the effect of $D$-galactosamine on hepatocellular metabolism is provided by the administration of uridine (6). Two repeated applications of equimolar amounts of uridine to galactosaminetreated rats result in a partial reversibility of the inhibition of glycosaminoglycan formation observed with $D$-galactosamine alone. The incorporation of $\left[{ }^{35} \mathrm{~S}\right]$ sulfate into total glycosaminoglycans increases from 0.24 to 0.55 of control, and that into heparan sulfate from 0.12 to 0.45 of control (tab. 2). The application of uridine alone was without significant effects on the formation of total and specific ${ }^{35} \mathrm{~S}$-labeled glycosaminoglycans (tab. 2). It should be noted that uridine was without effect on galactosamine-induced inhibition of $\left[{ }^{35}\right.$ S]glycosaminoglycans synthesis when both compounds were applied simultaneously for shorter periods of time than $3 \mathrm{~h}$. Furthermore, under these conditions uridine alone caused a significant depression of liver ${ }^{35}$ S ] glycosaminoglycàn formation (results not shown).
Ion exchange chromatographic distribution of $\left[{ }^{35} \mathrm{~S}\right]$ glycosaminoglycans from normal and galactosaminetreated liver

To detect gross structural differences between $\left[{ }^{35} \mathrm{~S}\right]$ glycosaminoglycans isolated from normal and galactosamine-treated rat liver, respectively, their elution profiles on Dowex $1 \times 2$ were recorded (fig. 4). In general, unfractionated glycosaminoglycans obtained from rat liver treated for $5 \mathrm{~h}$ with $700 \mathrm{mg} / \mathrm{kg}$ of $D$-galactosamine tended to elute at higher ionic strength from Dowex than those from normal liver. With $1.25 \mathrm{~mol} / 1$ of $\mathrm{NaCl}$ 0.4 and 0.62 of total glycosaminoglycan-associated radioactivity of injured and untreated liver, respectively, were recovered in the effluent. The elution profile of nitrous acid-labile glycosaminoglycans, which are the predominant type in liver, was similar for both injured and normal rat liver up to $1.5 \mathrm{~mol} / 1$ of $\mathrm{NaCl}$. At $2.0 \mathrm{~mol} / \mathrm{l}$ of $\mathrm{NaCl}$, however, about 0.2 of heparan $\left[{ }^{35} \mathrm{~S}\right.$ ]sulfate from normal liver and less than 0.02 from treated liver were desorbed from the column. As shown in figure 4 further differences were observed for dermatan $\left[{ }^{35} \mathrm{~S}\right]$ sulfate at $1.5 \mathrm{~mol} / \mathrm{l}$ and for chondroitin $\left[{ }^{35} \mathrm{~S}\right]$ sulfate at 1.25 and $2.0 \mathrm{~mol} / 1$ of $\mathrm{NaCl}$.

\section{Concentration of glucosamine- and galactosamine- containing glycosaminoglycans in D-galactosamine- treated liver}

The foregoing experiments showed that soon after application of the hepatotoxic $D$-galactosamine predominant inhibitory effect is on the incorporat on of $\left[{ }^{35} \mathrm{~S}\right]$ sulfate into heparan sulfate, whereas that into chondroitin sulfate and dermatan sulfate is only slightly impaired. Consequently, the ratio of concentration of glucosamine- to galactosamine-containing glycosaminoglycans should decrease in the early phase of galactosamino-induced liver damage. The results presented in table 3 verify that $5 \mathrm{~h}$ after administration of the drug the glucosamine/galactosamine ratio in total hepatic glycosaminoglycans is decreased by about $50 \%$ due to

Tab. 2. Effect of uridine on the $D$-galactosamine-induced inhibition of the incorporation of ${ }^{35}$ S $\mid$ sulfate into glycosaminoglycans of liver.

Rạts received simultaneously $200 \mathrm{mg} / \mathrm{kg}$ body weight and an equimolar amount of uridine $(272 \mathrm{mg} / \mathrm{kg})$ or a similar volume of $\mathrm{NaCl}$ (1. treatment). The same dose of uridine or an identical volume of $\mathrm{NaCl}$ was reapplied $3 \mathrm{~h}$ later (2. treatment). $3 \mathrm{~h}$ after the last injection and $30 \mathrm{~min}$ before decapitation $37 \mathrm{MBq}$ of $\left[^{35} \mathrm{~S}\right]$ sulfate were given to the rats. The incorporation of the isotope into the various types of glycosaminoglycans was assayed as described in fig. 1 . The data are the mean \pm S.D. of 3 separate experiments.

\begin{tabular}{|c|c|c|c|c|}
\hline \multirow[t]{2}{*}{ 1. Treatment } & \multirow[t]{2}{*}{ 2. Treatment } & \multicolumn{3}{|c|}{$\begin{array}{l}\text { Incorporation of }\left[^{35} \mathrm{~S}\right] \text { sulfate into specific gly cosaminoglycans } \\
{[\mathrm{kBq} / \mathrm{g} \text { liver dry weight] }}\end{array}$} \\
\hline & & Heparan sulfate & Dermatan sulfate & Chondroitin sulfate \\
\hline $\begin{array}{l}\mathrm{NaCl} / \mathrm{NaCl} \\
\mathrm{NaCl} / \text { uridine } \\
D \text {-Galactosamine/saline } \\
D \text {-Galactosamine/uridine }\end{array}$ & $\begin{array}{l}\mathrm{NaCl} \\
\text { Uridine } \\
\mathrm{NaCl} \\
\text { Uridine }\end{array}$ & $\begin{array}{l}1.59 \pm 0.09 \\
1.78 \pm 0.16 \\
0.19 \pm 0.04 \\
0.72 \pm 0.16\end{array}$ & $\begin{array}{l}0.37 \pm 0.03 \\
0.35 \pm 0.04 \\
0.24 \pm 0.09 \\
0.27 \pm 0.09\end{array}$ & $\begin{array}{l}0.03 \pm 0.01 \\
0.04 \pm 0.01 \\
0.04 \pm 0.02 \\
0.07 \pm 0.02\end{array}$ \\
\hline
\end{tabular}




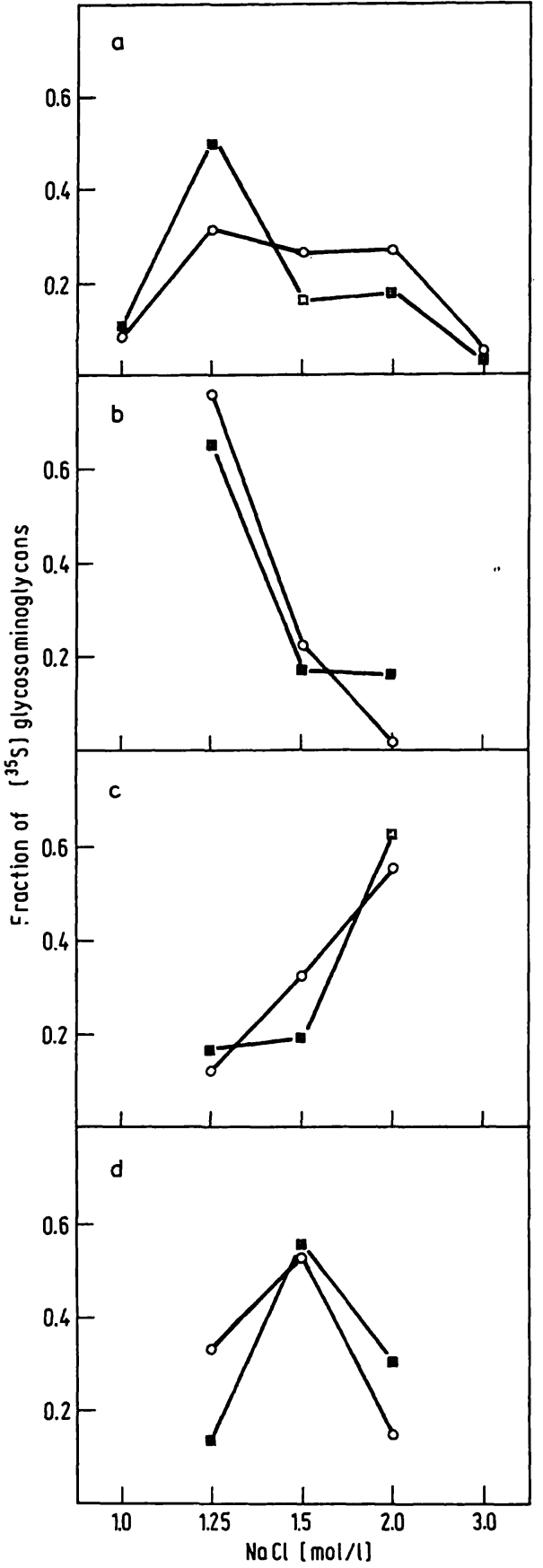

Fig. 4. Ion-exchange chromatography of $\left[{ }^{35}\right.$ S $]$ glycosaminoglycans from normal and galactosamine-injured liver.

Rats were treated with $D$-galactosamine, $700 \mathrm{mg} / \mathrm{kg}$ body weight or a similar volume of saline (control). $5 \mathrm{~h}$ later each animal received $3.7 \mathrm{MBq}$ of $\left[{ }^{35} \mathrm{~S}\right]$ sulfate and was sacrificed $30 \mathrm{~min}$ thereafter. Total glycosaminoglycans were isolated from the liver and applied to a column of Dowex $1 \times 2$, which was eluted with a gradient of stepwise increasing concentration of $\mathrm{NaCl}$. Each fraction of the effluent was subjected to chemical and enzymatic analysis to quantitate the specific types of glycosaminoglycans. Their relative distribution among the various portions expressed as fraction of total specific glycosaminoglycan was calculated. Because of low radioactivity the fractions eluted with 1.0 and $3.0 \mathrm{~mol} / 1$ of $\mathrm{NaCl}$ were not identified. The elution profiles of labeled unfractionated glycosaminoglycans (a), heparan sulfate (b), dermatan sulfate (c), and chondroitin sulfate (d) from galactosamine treated (•-) and control rat liver $(\bullet-)$ are shown.
Tab. 3. Concentration of glycosaminoglycan-bound glucosamine and galactosamine in normal and D-galactosaminetreated rat liver.

Rats were treated for $5 \mathrm{~h}$ with $700 \mathrm{mg} / \mathrm{kg}$ body weight or with a similar volume of $\mathrm{NaCl}$.

The defatted livers were proteolysed, precipitated with trichloroacetic acid and the neutralized supernatant was applied to a columun of Dowex $1 \times 2$.

The uronic acid-positive material eluting between 0.5 and $3.0 \mathrm{~mol} / 1$ of $\mathrm{NaCl}$ was precipitated with cetyl-pyridinium chloride, hydrolysed and submitted to quantitative determination of hexosamines by liquid column chromatography. The results represent the mean \pm S.D. of 3 experiments in each group.

\begin{tabular}{llll}
\hline Treatment & $\begin{array}{l}\text { Concentration of } \\
\text { hexosamines in liver } \\
\text { [nmol/g defatted liver] }\end{array}$ & $\begin{array}{l}\text { Glucosamine/ } \\
\text { galactosamine }\end{array}$ \\
& Glucosamine & Galactosamine \\
\hline $\mathrm{NaCl}$ & $110 \pm 9$ & $60 \pm 6$ & 1.8 \\
$D$-Galactosamine & $74 \pm 17$ & $75 \pm 5$ & 1.0 \\
\hline
\end{tabular}

a depression of glucosamine- and a slight increase of galactosamine-containing glycosaminoglycans. In later stages of liver injury even more pronounced changes of this ratio were observed (not shown).

\section{Discussion}

The synthesis of the various types of glycosaminoglycans in normal but not in regenerating rat liver is differently inhibited by $D$-galactosamine. Marked uridylate deficiency, which is the primary effect of $D$-galactosamine in resting liver (20), does not occur in regenerating liver, mainly because of accelerated de novo synthesis of pyrimidine (26). Pretreatment of the rats with uridine resulted in a partial reversibility of the inhibition. Since uridine administered alone for shorter periods than $3 \mathrm{~h}$ before decapitation also impaired the incorporation of $\left[{ }^{35} \mathrm{~S}\right]$ sulfate into liver glycosaminoglycans the dose scheme described in table 2 was chosen. It might, however, not be optimal (e.g. rather low dose of uridine (3)), for a complete reversion of the galactosamine effect on liver glycosaminoglycan synthesis.

The molecular mechanisms underlying the observed inhibition of proteoglycan synthesis in the very early phase of galactosamine-provoked liver damage are not yet clear. As in the case of diminished glycoprotein synthesis (27) it is difficult to differentiate between inhibition of synthesis of the core protein and the polysaccharide chain moiety. The use of derivatives of $\beta$ $D$-xyloside (28), an exogenous acceptor of glycosaminoglycan synthesis, might give an indication of the level at which the depression of proteoglycan synthesis is taking place. A selective impairment of the carbohydrate sulfation, however, seems unlikely since the concentration of 3 '-phosphoadenosine- $5^{\prime}$-phosphosulfate is not diminished during the phase of maximum 
inhibited heparan sulfate production; the pattern of elution of heparan sulfate from Dowex is similar for the material from normal and galactosamine treated liver; in parallel with the reduction of $\left[{ }^{35} \mathrm{~S}\right]$ sulfate incorporation there was a reduction of glucosamine-containing glycosaminoglycans. Thus, $\left[{ }^{35} \mathrm{~S}\right]$ sulfate incorporation is probably a true reflection of glycosaminoglycan chain synthesis.

The question whether the increase in UDP-glucosamine and UDP-galactosamine in $D$-galactosamine treated liver

(3) leads to incorporation of non $\mathrm{N}$-acetylated, unnatural amino sugars similar to that in glycogen (aminoglycogen) $(29,30)$ remains to be answered.

The rapidly occurring, long-lasting and strong inhibition of the formation of proteoheparan sulfate contrasts with the rather transient and slight depression of the production of the galactosamine containing glycosaminoglycans. This might be a consequence of their different metabolic turnover, being highest for proteoheparan sulfate (14), and their different cellular sites of synthesis. The hepatocyte as the major if not the exclusive heparan sulfate producing cell type in liver $(14,16,31)$ is sensitive to $D$-galactosamine, whereas $v$. Kupffer cells are not target cells for galactosamine-induced uridylate trapping (32). Although it has not been shown before that isolated sinusoidal cells are capable of synthesizing chondroitin sulfate and dermatan sulfate in significant amounts, our results would be in agreement with this assumption. Alternatively, the almost galactosamine-refractory synthesis of chondroitin sulfate and dermatan sulfate in liver might be due to synthesis in non-hepatic cells, e.g. cellular components of the blood. The greatly exaggerated synthesis of galactosamine-containing glycosaminoglycans in later stages of injury thus might be due to the large accumulation of inflammatory cells in the parenchyma (2), of which polymorphonuclear leukocytes and monocytes were shown to synthesize predominantly chondroitin sulfate and dermatan sulfate, respectively (33). Unspecific, inflammatory reactions might also be responsible for the observed increase in the proportions of synthesized chondroitin sulfate and dermatan sulfate in sham-operated livers (tab. 1) as compared with saline-injected control rat livers (tab. 2). Undoubtedly, the variable contribution of inflammatory blood cells to the metabolism of glycosaminoglycans in injured liver deserves more serious consideration than it has previously received.

Apart from uncertainty as to the cellular origin of hepatic glycosaminoglycans, the present study does not discriminate between the various subcellular compartinents of proteoglycans, in particular of proteoheparan sulfate. Since hepatocellular proteoheparan sulfate resides predominantly in the pericellular compartment $(14-17,34)$ it is likely that $D$-galactosamine reduces markedly the content of cell coat heparan sulfate. This conclusion is supported by recent results demonstrating a significant reduction of content and synthesis of an as yet unidentified, high molecular weight, sulfated cell surface glycoprotein in galactosamine-injured liver cell plasma membranes (34). The pathobiochemical significance of the diminution of cell surface proteoheparan sulfate remains to be determined. The proposed functions of this compound suggest effects on the coordinated exchange and/or absorption of electrolytes, metabolites and fluids, on the accessibility of cell surface receptors, on the intercellular recognition, adhesion and communication and on the proliferating activity.

Further studies are concerned with the functional meaning of reduced proteoheparan sulfate for the mechanism of cell injury and with the question of whether the observed changes are common to several types of toxic liver cell injury. Furthermore, extended time-course studies should show whether the greatly stimulated synthesis of glycosaminoglycans in later stages of injury represents initial molecular and cellular events leading to the fibrotic transition of the organ, if the hepatotoxic $D$-galactosamine is applied continuously $(36,37)$.

\section{References}

1. Reutter, W., Lesch, R., Keppler, D: \& Decker, K. (1968), Naturwissenschaften 55,497 .

2. Keppler, D., Lesch, R., Reutter, W. \& Decker, K. (1968), Exp. Mol. Pathol. 9, 279-290.

3. Dẹcker, K. \& Keppler, D. (1974), Rev. Physiol. Biochem. Pharmacol. 7l, 78-1.06.

4. Decker, K. \& Keppler, D. (1972), in Progress in Liver Diseases (Popper, H. \& Schaffner, F., eds.) Vol. 4, pp. 183-199, Grune and Stratton, New York.

5. Shinozuka, H., Farber, J. L., Konishi, Y \& Anukarahanonta, T. (1973), Fed. Proc. 32, 1516-1526.

6. Keppler, D. O. R., Pausch, J. \& Decker, K. (1974), J. Biol. Chem. 249, 211-216.

7. Keppler, D., Rudigier, E., Bischoff, E. \& Decker, K. (1970), Eur. J. Biochem. 17, 246-253.

8. Keppler, D., Reutter, W., Lesch, R. \& Decker, K. (1969), Verh. Dtsch. Ges. Innere Med. 75, 361-363.

9. Hofmann, F., Wilkening, J., Nowack, J. \& Decker, K. (1976), Hoppe-Seyler's Z. Physiol. Chem. 357, 427-433.

10. El Mofty, S., Scrutton, M. C., Serroni, A., Nicolini, C. \& Farber, J. L. (1975), Am. J. Pathol. 79, 579-596.

11. Reutter, W. \& Bachmann, W. (1971), Verh. Dtsch. Ges. Innere Med. 77, 1177.

12. Bachmann, W., Harms, E., Hassels, B., Henninger, $H$. \& Reutter, W. (1977), Biochem. J. 166, 455-462.

13. Bạchmann, W. \& Reutter, W. (1979), Hoppe-Seyler's Z. Physiol. Chem. 360, 81-87.

14. Oldberg, A., Höök, M., Öbrink, B., Pertoft, H. \& Rubin, K. (1977), Biochem. J. 164, 75-81.

15. Oldberg, A., Kjellén, L. \& Höök, M. (1979), J. Biol. Chem. 254, 8505-8510.

16. Yamamoto, K. \& Terayama, H. (1973), Cancer Res. 33, $2257-2264$. 
17. Akasaki, M., Kawasaki, T. \& Yamashina, I. (1975), FEBS Lett. 59, 100-104.

18. Kraemer, P. M. (1971), Biochemistry 10, 1445-1451,

19. Ohnishi, T., Ohshima, E. \& Ohtsuka, M. (1975), Exp. Cell Res. 93, 136-142.

20. Reutter, W., Bauer, Ch., Bachmann, W. \& Lesch, R. (1975), in Liver regeneration after experimental injury (Lesch, $\dot{R}$. \& Reutter, W., eds.) pp. 259-272 Stratton Intercontinental Book Corp., New York, USA.

21. Higgins, G. M. \& Anderson, R. M. (1931), Arch. Pathol. 12, 186-202.

22. Greiling, H. \& Stuhlsatz, H. W. (1969), Hoppe-Seyler's Z. Physiol. Chem. 350, 449-456.

23. Gressner, A. M., Pazen, H. \& Greiling, H. (1977), HoppeSeyler's Z. Physiol. Chem. 358, 825-833.

24. Gressner, A. M., Pazen, H. \& Greiling, H. (1977), Experientia $33,1290-1292$.

25. Ping Wong, K. \& Yeo, T. (1979), Biochem. J. 181, 107-110.

26. Bresnik, E. (1965), J. Biol. Chem. 240, 2550-2556.

27. Reutter, W., Keppler, D., Lesch, R. \& Decker, K. (1969), Verh. Dtsch. Ges. Innere Med. 75, 363-365.

28. Sudhakaran, P. R., Sinn, W. \& Figura, K. von (1980), HoppeSeyler's Z. Physiol. Chem. 361, 337.
29. Meszaros, K., Mandl, J., Antọni, F. \& Garzo, T. (1976), FEBS Lett. 71, 215-219.

30. Mandl, J., Garzo, T., Meszaros, K. \& Antoni, F. (1979), Biochim. Biophys. Acta 586,560-567.

31. Prinży, R., Klein, M., Ulirich, K., Sudhakaran, P. R. \& Figura, $K$. von (1979) in Glycoconjugates, Proc. 5th Int. Sympos. Kiel (Schauer, R., Boer, P., Buddecke, E., Kramer, M. F., Vliegenthart, J. F. G. \& Wiegandt, H., eds.) pp. 337-338, Thieme, Stuttgart.

32. Hofmann, F., Wagle, S. R. \& Decker, K.:(1976), HoppeSeyler's Z. Physiol. Chem. 357, 1395-1400.

33. Hasumi, F. \& Mori, Y. (1980), Biochem. Med. 23, 6-16.

34. Kjellén, L., Oldberg, A., Rubin, K. \& Höök, M. (1977), Biochem. Biophys. Res. Commun. 74, 126-133.

35. Bertrand, F., Veissiere, D. \& Picard, J. (1979), Digestion 19, 284-291.

36. Lesch, R., Keppler, D., Reutter, W., Rudigier, J., Oehlert, W. \& Decker, K. (1970), Virchows Arch. Abt. B Zellpathol. 6, 57-71.

37. Funatsu, K., Ishii, H., Shigeta, Y., Morita, A. \& Tsuchiya, M. (1978), Acta Hepato-Gastroenterol. 25, 97-104.

Prof. Dr. med. A. M. Gressner

Abteilung Klinische Chemie und Pathobiochemie Klinisch-Chemisches Zentrallaboratorium der Medizinischen Fakultät der RWTH Aachen Goethestr. 27-29

D-5100 Aachen 